\title{
Purchasing Vegetables from Different Channels: A Comparative Study on Factors Affecting the Choice of Channel
}

\author{
Dr. Rezwanul Huque Khan ${ }^{a^{*}}$, Farah Naz Aditi ${ }^{\mathrm{b}}$ \\ ${ }^{a}$ Associate Professor, Institute of Business Administration, University of Dhaka, Dhaka, Bangladesh. \\ ${ }^{b}$ Assistant Manager, Central Finance Team, Standard Chartered Bank, Dhaka, Bangladesh.
}

*Corresponding Author: Dr. Rezwanul Huque Khan, Associate Professor, Institute of Business

Administration, University of Dhaka, Dhaka, Bangladesh.

\begin{abstract}
Vegetables as the important sources of many nutrients are a staple food of many countries across the world. In Bangladesh, while the household expenditure for vegetable consumption has increased over the years, customers here have exhibited varied purchasing patterns of vegetables in terms of their usage of channels. This study investigates the factors for which customers choose a particular channel to purchase vegetables and, compares and ranks those factors across different channels (i.e., local market, supermarket, online market and multiple channels). Our study shows as a channel to purchase vegetables, supermarkets and online markets have taken a reasonable customer share from that of the local market. We found quality and variety of vegetables are the two most important factors that induce consumers to purchase vegetables from the local market while consumers prefer the supermarket mostly due to its ambiance followed by the availability of other daily necessities in the supermarket. On the other hand, the main reason consumers opt for online purchase of vegetables is convenience and the availability of other daily necessities. We also explore how the customers' preferences of factors vary while they purchase from multiple channels (i.e., local market and supermarket, supermarket and online market etc.). The findings of this study provide major implications for the marketers and entrepreneurs which we articulate at the end.
\end{abstract}

Key words: Vegetable purchase, local market, supermarket, online market, multiple channel, Bangladesh

\section{INTRODUCTION}

Vegetable is an integral part of our diet. It helps to not only maintain a healthy body but is also a major component of the South Asian or Bangladeshi cuisine. It is a staple food in Bangladesh, with the second highest intake after rice. According to Household Income and Expenditure Survey 2016, 9.24\% of total household expenditure on food and drink in Bangladesh is spent on vegetables and this percentage share has increased by almost $2 \%$ in the last five years (BBS, 2016). Hence, vegetable is one of the frequently purchased food items in the country.

Traditionally, perishable items such as vegetables were sold only in local/flea market (Kachha Bazar). Vegetable was also sold by local vendors who would employ door to door selling technique. However, due to the rise of the middle class and the subsequent enhancement of shopping experience demanded by the consumer, the concept and growth of the supermarket emerged in the country and a handful of such supermarkets started selling vegetables on shelf (Masoom et al., 2015).The lifestyle changes also made an impact on purchasing behaviour of consumers owing to rise in spendable income, rise in dual income groups, less time to spend in local mandi markets, accessibility to online purchase platforms, etc. (Akpinar et al., 2009). Thus, products that were once only available in traditional channels slowly started to transition to modern retail stores/supermarket. According to the BSOA (Business Supermarkets Owners' Association), currently there are 121 supermarkets in the country. However, the industry is largely dominated by three major players - Shwapno (59 Outlets), Agora (13 Outlets) and Meena Bazar (18 Outlets). Once a key competitor, Nandan, now holds just two stores. In terms of distribution network and competitive prices, Swapno has entrenched itself as the market leader, whereas, Agora and Meena Bazar are viewed as market leaders in terms of quality and services (Light Castle Partners, 2015). 
The economic boom and urbanization wave that swept the country in the past decade increased female participation in the workplace and made the overall lifestyle of city dwellers busier than ever before. Under such circumstances, the idea of online grocery shops came aboard and it started to serve a niche market of professionals mainly, who find it convenient to get their groceries delivered at their footsteps. Chaldal.com is one of the first market players and is a popular name in the online arena. Even supermarkets grabbed the opportunity to penetrate into this market and launched online subsidiaries such as Meenaclick and Shwapno.com (Deshiz, 2018). Although the local market is still the market leader in terms of vegetable purchase by consumers, supermarkets and online markets is rapidly gaining market.

However, there is a lack of enough literature regarding the factors of vegetable purchase behaviour in various channels of our country. This topic deserves special attention because it serves both the marketeers, who need to understand what influences the vegetable purchasing behaviour as well as the entrepreneurs, who are planning to gain an entry into the market in face of intense competition. Market research is needed to probe into the factors that influence consumers to choose a particular channel for vegetable purchase for example, supermarket/online market over local market and vice versa. Thus, the research aims to conduct a comparison on the factors affecting consumers' choice of different channels for purchasing vegetable and provide the implications of the findings.

\section{LiTERATURE REVIEW}

We have gone through various literature focusing on consumers' vegetable purchase behaviour. We tried to find out the factors affecting vegetable purchase in general and later on the place of purchase.

Balaji (2015), in a study, pointed out that the location of vegetable purchase depends on socioeconomic background of consumers, their personality, and past purchase experience. Sinha et al. (2002) state that demographics and individual values also can affect this choice. Again, Singh and Neeraj (2018) in their study found that about 35\% of the respondents preferred buying vegetables more than once a week, while $26 \%$ preferred buying daily and $18 \%$ preferred to buy only once in a week. It is seen that $71.53 \%$ of the respondents prefer the local market for buying vegetables, followed by $19.71 \%$ who preferred supermarkets, $13.14 \%$ preferred wholesale market while only $1.46 \%$ preferred Online purchase and 3.65\% chose other. The respondents also revealed that they choose local market over supermarket due to availability of diverse and fresher produce at cheaper prices and proximity to their home.

Herath US (2019) on the other hand found that nearly $34 \%$ of the respondents bought vegetables twice a week, followed by $30 \%$ of respondents who purchased once a week and a significant number who purchased vegetables whenever they needed it. According to Herath US (2019), most respondents visit more than one location for vegetable purchase. Green grocer (76\%) was the prime location followed by organized supermarket (31\%) and small retail shops (44\%). A majority of 54\% of respondents selected green grocers as place of purchase of more than $50 \%$ of vegetables.

Finzer et al. (2013) pointed out that households purchased fruits \& vegetable items 4 times per week on average and 99\% households reported purchasing some fruit or vegetables from traditional retailers (street vendor, open market, or mom and pop grocery store). Only 13 households (5.3\% of total sample) reported purchasing any food items from the supermarket.

In terms of factors affecting vegetable purchase decision, Gunden \& Thomas (2012) highlighted that consumers pay more attention to freshness, taste and hygiene attributes of fresh fruits and vegetables than they do to price and nutritional value. Chikkamath et al. (2012) advanced that in case of food items, particularly vegetables, non-price factors such as quality, expiry date and nutritional values are more important.

Solgaard and Hansen (2003) identified several store attributes were considered important for the consumer's evaluation of stores. Anuradha (2015) in her study concludes that the choice of a purchase channel is determined by the availability of good quality products. This is supported by the results from a research carried out in Kenya by the Research Solutions Africa (RSA) Ltd. The same resulted were resonated in the study of Herath US, where respondents pointed out the quality of products as the key determinant while choosing a channel for purchase, followed by easiness of selection and lower prices. 
Finzer et al., 2013 examines associations between consumer characteristics, beliefs, and preferences and fruit and vegetable (FV) purchasing and intake in South Delhi, India. Fruits and Vegetables from a supermarket or cooperative store was associated with giving a higher mean rating of importance to the set of factors characteristic of modern retailing: air conditioning, buying everything from one store, credit and debit card facilities, and special offers. Overall, respondents rated price, appearance, being able to touch items, and cleanliness as the most important factors in buying fruits and vegetables.

Imtiaz et al. (2017) identified eight major factors for which people prefer super-stores. According to the survey, consumers ranked convenience (in terms of suitable operating time, adjacent location, one stop household requirements fulfilment, hassle free environment etc.) as first priority for choosing super-store shopping, which is mostly absent in the traditional option for the similar products. Consumers ranked cleanliness as their second criterion for shopping there, which is very much desired to them but not available in the traditional shopping environment. Secured environment (where the chances of losing product, pick pocket, snatching, unwelcome touching to ladies most probably do not arise) ranked as their third priority among the eight criteria for choosing this kind of shopping. Appropriate weight and higher quality both simultaneously became fourth priority whereas consumers have chosen product variety as sixth criterion. Consumers put responsible price (compared to the facilities offered) in seventh position in the ranking for choosing this type of shopping. Consumers ranked easy to pay (one point of transaction for all shopping, different cards' acceptability) as eighth criterion for choosing this type of superstores.

Slamet \& Nakayasu (2016) conducted a study on Consumers' Choice for Vegetable Market Channels in Indonesia and concluded that quality, safety, price, easiness \& availability were influential factors for consumers to shop at traditional market. Meanwhile, modern markets meet the needs of higher income, well-educated and employed women who are reside in urban area and have concerned on store attributes and brand \& traceability information.

As such, extant literature identifies different variables e.g., price, quality, variety, ambiance, convenience etc. which directly affect customers' decision of purchasing vegetables in general or in a particular channel. However, hardly any work has been found dealing with the comparison of different factors affecting the purchase decision of vegetables in various channels. This study considers this gap in information as an opportunity to investigate further into the topic and provide a useful comparison of the purchase factors in different channels of vegetable purchase.

\section{Methodology}

This study adopts quantitative method to investigate customers' choice of preferred channels and compares the data across three different channels. Data was collected from both primary and secondary sources. The source of secondary data was various relevant books, journals, newspapers and online sites. For collecting primary data, a structured questionnaire was developed and used for survey. The questionnaire developed had mostly closed ended questions which included checklist of items, MCQ questions and few statements with Likert scale. The first section of the questionnaire was regarding demographic variables of the respondents while the second section focused on their preferences and purchase. The respondents were required to answer how frequently they visit purchase vegetables and their primary location of purchase. The purpose of these two questions was to determine their purchase pattern. The next questions were on different factors a consumer considered important to select the location/channel to purchase vegetable. It also included questions to explore the importance of those factors in channels other than their preferred one. To find out the importance of those factors, respondents were asked to rate the importance of a factor in a certain channel with 5-point Likert scale were provided wherein 1 indicated "Not at all important" and 5 represents "Extremely Important". Since the sampling frame for the customers who purchase vegetables in Dhaka city cannot be determined, convenience sampling was used to select the respondents. The formula used to determine the sample size for our research is: $n=\left(\mathrm{z}^{2} \mathrm{pq}\right) / \mathrm{d}_{0}{ }^{2}$; Where, $\mathrm{n}=$ sample size; $\mathrm{z}=$ cut-off value for desired confidence level; $\mathrm{P}=$ proportion of households able to afford the basic amenities $\mathrm{q}=1-\mathrm{p}$ and $\mathrm{d} 0=$ precision. Here, we desire a confidence level of $90 \%$, which yields a $\mathrm{z}$-value of 1.65 and a precision level of $\pm 5.5 \%$. The value of $\mathrm{p}$ and $\mathrm{q}$ will be taken as 0.5 because we want equal representation of the population. Hence, the required sample size for 
Purchasing Vegetables from Different Channels: A Comparative Study on Factors Affecting the Choice of Channel

this study is $\mathrm{n}=(1.65 * 0.5 * 0.5) / 0.055^{2}=220$. The questionnaire was supplied to 250 customers of Dhaka city at local markets and various super shops and we received 244 filled in questionnaires.

The collected data was entered into IBM SPSS Statistics software, and frequency analysis and descriptive statistics were used to analyze the data.

\section{ANALYSIS \& FINDINGS}

\subsection{Vegetable Buying Behaviour}

In our study, we investigate the vegetable purchase behaviour by two major parameters- Channel and Frequency of Purchase.

\subsubsection{Channel}

Our study tried to find out the place of buying vegetables. We found out that vegetable buying place is not a matter of simple binary choice, rather it is a combination of 2 or more places. We have found that $43.4 \%$ of the respondents purchase vegetable from only local market while $8.2 \%$ of the respondents purchase from only supermarket. $42.6 \%$ purchase vegetables from both local market and supermarket., $3.3 \%$ avail services from all channels of local, super and online market.

Table1. Place for buying vegetables

\begin{tabular}{|l|l|l|}
\hline Channel & Frequency & Percent (\%) \\
\hline Local Market (Wet market, Road side shops \& Vans) & 106 & 43.4 \\
\hline Supermarket (Agora, Shwapno, Meena Bazar) & 20 & 8.2 \\
\hline Online (Chaldal/Meena Click/Swapno) & 2 & .8 \\
\hline Multiple Channels & $\mathbf{1 1 6}$ & $\mathbf{4 7 . 5}$ \\
\hline Local market and Supermarket & 104 & 42.6 \\
Local market and online & 0 & 0 \\
Supermarket and online & 4 & 1.6 \\
Local market, Supermarket and online & 8 & 3.3 \\
\hline
\end{tabular}

\subsubsection{Frequency}

Our study also found out the frequency of buying vegetables. We have found that $35.2 \%$ of the respondents purchase vegetable once a week. On the other hand, $32.8 \%$ of them purchase vegetables 3 or more times per week. $25.4 \%$ of respondents purchase twice a week and only $6.6 \%$ purchase vegetables only once a month.

Table2. Frequency of buying vegetables

\begin{tabular}{|l|l|l|}
\hline & Frequency & Percent (\%) \\
\hline Once a Week & 86 & 35.2 \\
\hline Twice a Week & 62 & 25.4 \\
\hline 3 times or more a Week & 80 & 32.8 \\
\hline Once a Month & 16 & 6.6 \\
\hline
\end{tabular}

\subsection{Factors Affecting Vegetable Purchase in Various Channels}

In our study, we try to identify and rank the various factors that affect consumer's choice of a channel. A list of factors relevant to vegetable purchase was provided and we asked our respondents to rate the importance of the listed factors (for their choice of a channel for vegetable purchase) on a Likert scale where 1 indicates very low and 5 indicates very high. The study aims to create a comparison of the factors that influence a consumer to use a particular channel for vegetable purchase. First, we discuss the factors in three distinct channels- local, super and online market and then we discuss the factors affecting the choice of using multiple channels.

\subsubsection{Local Market}

From table 3 we can see that consumers feel that; Quality and Variety of vegetables are the two most important factors that induce consumers to purchase vegetables from the local market. They rate Price as a moderately important factor, followed by the proximity from home. However, it is seen that, when consumers go to local market, their sole purpose is most likely to be vegetable purchase as they are quite indifferent to the availability of variety of other products and care the least about the ambiance while purchasing in local market. 
Purchasing Vegetables from Different Channels: A Comparative Study on Factors Affecting the Choice of Channel

Table3. Factors Affecting Purchase Decision in Local Market

\begin{tabular}{|l|l|l|l|l|}
\hline Evaluative Criteria & Mean & Std. Deviation & Skewness & Kurtosis \\
\hline Price & 3.62 & 0.85 & -0.39 & 0.32 \\
\hline Quality of vegetables & 3.96 & 1.00 & -0.72 & -0.09 \\
\hline Varieties of vegetables & 3.88 & 0.90 & -0.70 & 0.78 \\
\hline Ambiance & 2.34 & 1.29 & 0.57 & -0.89 \\
\hline Convenience (saves time, cost etc.) & 3.18 & 1.42 & -0.17 & -1.31 \\
\hline Availability of other daily necessities & 2.61 & 0.79 & 0.21 & -0.03 \\
\hline Proximity from home & 3.29 & 1.08 & -0.07 & -0.42 \\
\hline
\end{tabular}

\subsubsection{Supermarket}

We have found out from our study that consumers prefer the supermarket for vegetable purchase mostly due to its ambiance. The scope to shop for other daily necessities at the same time and the varieties offered at super shops are also very important reasons to choose the supermarket. Quality and convenience are moderately important factors, whereas, price being the least important factor is an indicator that supermarket shoppers for vegetable might not be very price conscious.

Table4. Factors Affecting Purchase Decision in Supermarket

\begin{tabular}{|l|l|l|l|l|}
\hline Evaluative Criteria & Mean & Std. Deviation & Skewness & Kurtosis \\
\hline Price & 3.09 & 0.88 & 0.04 & 0.08 \\
\hline Quality of vegetables & 3.25 & 0.79 & 0.03 & -0.04 \\
\hline Varieties of vegetables & 3.53 & 1.03 & -0.62 & 0.03 \\
\hline Ambiance & 3.70 & 0.75 & -0.04 & -0.38 \\
\hline Convenience (saves time, cost etc.) & 3.18 & 1.42 & -0.17 & -1.31 \\
\hline Availability of other daily necessities & 3.54 & 0.84 & -0.38 & 0.30 \\
\hline Proximity from home & 3.11 & 1.43 & -0.07 & -1.29 \\
\hline
\end{tabular}

\subsubsection{Online Market}

We have also found out from our study that the main reason consumers opt for online purchase of vegetables is Convenience followed by the availability of varieties of other products. The next factor is quality, followed by price- both being moderately important to consumers. The least important factors for online purchase are the Proximity from home and ambiance, which is explanatory since purchase on an online media is hardly affected by any such factors.

Table5. Factors Affecting Purchase Decision in Online Market

\begin{tabular}{|l|l|l|l|l|}
\hline Evaluative Criteria & Mean & Std. Deviation & Skewness & Kurtosis \\
\hline Price & 3.17 & 0.82 & -0.13 & 0.39 \\
\hline Quality of vegetables & 3.26 & 1.32 & -0.19 & -1.11 \\
\hline Varieties of vegetables & 3.41 & 0.88 & -0.20 & 0.32 \\
\hline Ambiance & 2.72 & 0.80 & -0.12 & 0.48 \\
\hline Convenience (saves time, cost etc.) & 3.54 & 1.24 & -0.30 & -0.88 \\
\hline Availability of other daily necessities & 3.47 & 1.33 & -0.46 & -0.95 \\
\hline Proximity from home & 2.93 & 0.68 & 0.09 & 1.05 \\
\hline
\end{tabular}

\subsubsection{Comparison Among Local, Super and Online Market}

Analysing all three together, we observed which factors are the most and least important in each channel. Table 6 shows that, the most important factor affecting vegetable purchase in a local market is Quality, whereas in a supermarket it is the ambiance and for online shops, it is the convenience offered. The second most important factor for both super shops and online marketplace is the availability of other daily necessities, providing customers a one-stop solution and for local markets, it is the greater varieties of vegetable available. We see that, consumers are least affected by the ambiance in both local markets and online shops, although for very different reasons. Whereas, the ambiance really does not have an impact on online purchasers, shoppers from local market might overlook it in comparison to factors they deem more important for choosing the channel. The least important factor for super shops is price. 
Purchasing Vegetables from Different Channels: A Comparative Study on Factors Affecting the Choice of Channel

Table6. Comparison among channels

\begin{tabular}{|l|l|l|l|}
\hline Evaluative Criteria & Local & Super & Online \\
\hline Price & 3 & 7 & 5 \\
\hline Quality of vegetables & 1 & 4 & 4 \\
\hline Varieties of vegetables & 2 & 3 & 3 \\
\hline Ambiance & 7 & 1 & 7 \\
\hline Convenience (saves time, cost etc.) & 5 & 5 & 1 \\
\hline Availability of other daily necessities & 6 & 2 & 2 \\
\hline Proximity from home & 4 & 6 & 6 \\
\hline
\end{tabular}

\subsection{Factors Affecting Vegetable Purchase in Multiple Channels}

Our study shows that, a large proportion of respondents $(47.5 \%)$ use more than one channel for purchasing vegetables. In fact, nearly $43 \%$ respondents use both local \&supermarket for vegetable purchase. Our study asked such respondents to choose first their most preferred channel and then to identify the factors inducing them to purchase from channels other than their preferred.

\subsubsection{First Choice- Local Market}

We found that out of 116 respondents who use multiple channels for vegetable purchase, 68 of them chose local market as their first choice. Then, these 68 respondents who chose local market as their most preferred channel were asked to rate the importance of the factors that influence them to use supermarket or online market instead of their preferred local market on a scale of 1 (least important) to 5 (most important).

Table7. Factors affecting purchase decision in Multiple Channels

\begin{tabular}{|l|l|l|}
\hline Evaluative Criteria & Supermarket & Online Market \\
\hline Price & 2.88 & 3.35 \\
\hline Quality of vegetables & 3.66 & 3.68 \\
\hline Varieties of vegetables & 3.41 & 3.94 \\
\hline Ambience & 4.29 & 2.68 \\
\hline Convenience (saves time, cost etc.) & 3.79 & 4.20 \\
\hline Availability of other daily necessities & 4.15 & 4.16 \\
\hline Proximity from home & 3.12 & 2.91 \\
\hline
\end{tabular}

It reflects that the respondents who are primary buyers in local market go to supermarket mainly for the better ambiance and due to the availability of other daily goods. Online shops provide convenience of getting vegetables home delivered along with other dailies, which is the primary reason to choose this channel for local market goers. We note that many local market goers also shop at supermarket when it provides greater convenience and at online market when they are offered good variety. The least important factor for supermarket shoppers is price, in line with shoppers whose first priority is super shop. In case of online shops, it is the ambiance.

\subsubsection{First Choice- Supermarket}

Out of 116 respondents who use multiple channels for vegetable purchase, 48 of them chose supermarket as their first choice. These 48 respondents then rated the factors of importance which affect their decision to go to local market or shop online for vegetables.

Table 8 shows us that, consumers whose first choice of channel is super shop occasionally visit local market mainly for the quality and variety, followed by convenience and price. Primary super shop buyers are also concurrent with primary local market goers- giving least importance to the ambiance and the availability of other necessities at local market.

On the other hand, consumers opt to choose the online marketplace instead of super shops mainly due to the convenience and varieties. Switching from super shop to online is moderately affected by a number of factors such as- the availability of other goods, quality of vegetables and price. The least important factor being ambiance is in line previous analysis.

Table8. Factors affecting purchase decision in Multiple Channels

\begin{tabular}{|l|l|l|}
\hline Evaluative Criteria & Local Market & Online Market \\
\hline Price & 3.66 & 3.29 \\
\hline Quality of vegetables & 4.11 & 3.45 \\
\hline
\end{tabular}


Purchasing Vegetables from Different Channels: A Comparative Study on Factors Affecting the Choice of Channel

\begin{tabular}{|l|l|l|}
\hline Varieties of vegetables & 3.98 & 3.83 \\
\hline Ambience & 2.93 & 2.42 \\
\hline Convenience (saves time, cost etc.) & 3.71 & 4.02 \\
\hline Availability of other daily necessities & 3.06 & 3.67 \\
\hline Proximity from home & 3.32 & 2.79 \\
\hline
\end{tabular}

\subsubsection{First Choice- Online Market}

Our analysis shows that out of the 116 Consumers, we did not find any respondent who chose multiple channel for vegetable purchase and also chose online shop as their first choice. It may be attributed to the fact that the e-commerce business for perishable food items is still in its introductory phase in the country. However, we found two customers who shop vegetables only from online markets.

\section{DISCUSSION}

It is seen from the study that, people usually purchase vegetables once a week and use multiple channels for their purchase, with local market being the most popular choice.

Local market is the popular choice mainly since customers give a great importance to the quality of vegetable available at local market. This can be related to the consumer perception that vegetables sold at local market are fresher since storage options are limited. Variety is also very important to consumers as local market often source native vegetables appealing to the local cuisine. Consumers also deem price as an important factor in choosing local market indicating that local market goers are price conscious and often bargain with the sellers.

Supermarket buyers place the highest level of importance on the ambiance- the cleaner shops with air conditioning and neatly arranged isles. They prefer supermarkets since it provides a one stop solution to other daily necessities and provides variety as well. However, consumers who prefer supermarkets are least bothered by price.

Although online shops are yet to gain a steady hold in the vegetable purchase market, consumers have already started to avail this option for the convenience and a variety of goods that it offers.

A large number of people use multiple channels for vegetable purchase since this is a daily necessity and might require buying on a short notice. As such, consumers often cannot afford to purchase from their favourite place and branch out to other options. However, it is seen that even for such customers who venture through other options than their preferred channel, the factors affecting purchase in the alternate channels hold true. As such, we can draw the conclusion that, the factors inducing customers to purchase vegetables from a channel is more or less same irrespective of their preference (first or second) of the channel.

Based on the insights derived from the analysis, our study suggests a few implications for entrepreneurs and marketers-

- Online markets for vegetables are an untapped sector in the country. However, with the booming economy coupled with urbanization, people will seek to shop from the comfort of their home even for products like vegetable. Thus, entrepreneurial opportunities are bound to succeed if the customer's need for convenience-such as timely delivery, accurate product delivery, availability of required products is fulfilled.

- It is seen that the local market is preferred by many due to the perception of freshness in vegetables of local market. Marketers have a role to play to communicate the presence of such attributes in vegetables available at super shops as well. This can help supermarkets attract customers who usually prefer local market.

- Consumers place a great deal of importance on the ambiance of the super shop. This can be an opportunity for super shop marketers to work towards the enhancement of the shopping experience for the customers for retention. For example, soothing music in the shop or setting up a food corner can create a unique and enjoyable experience.

- Online shops should ensure that they are able to meet the demand for not only a variety of vegetables but also other daily necessities. As such, online shops will be able to compete with super shops by offering a better price since operational costs for online marketplace is lower. 


\section{CONCLUSION}

As the country's food industry undergoes a massive overhaul, supermarket and online markets are the go of the town now. While local market was the most preferred channel for purchasing vegetables in the country, customers, to a large extent, now-a-days purchase vegetables from different channels like supermarket and online market. However, the factors that people seek in a place to purchase vegetable vary. The study shows the factors for which customers choose a particular channel to purchase vegetables and how the factor varies across the channels. Future studies should investigate whether the demographic variables have influence on the preference of attributes. Moreover, further investigation is also needed to explore whether the findings of this study could be generalized for other cities in the country. The study offers few useful recommendations for the marketers and also for the entrepreneurs that can be put into practice to provide superior customer service and gain consumer confidence for a much more profitable venture.

\section{REFERENCES}

[1] Akpinar, M.G., Aykin, S.M., Sayin, C. and Ozkan, B. 2009. The role of demographic variables in purchasing decisions on fresh fruit and vegetables. Journal of Food, Agriculture and Environment. 7 (3/4): 106-110.

[2] Anuradha A (2015) Analysis on the behavioral Pattern of Organized and Unorganized Vegetable Retail Shoppers. Bonfring International Journal of Industrial Engineering and Management Science (5)2: 90- 94.

[3] Balaji P (2012) Retail Store Choice for Fruits and Vegetables: A Study on Perception, Preferences and Buying Behaviour of Consumers. Doctor of Philosophy Dissertation in Agribusiness and Management Development. Centre for Agricultural and Rural Development Studies, Tamil Nadu Agricultural University, Coimbatore.

[4] Bangladesh 3rd in Global Vegetable Production. (2016, January 29). Retrieved from banglanews24.com: https://www.banglanews24.com/national/article/49352/ Bangladesh-3rd-in-global-vegetable-production.

[5] Bangladesh Bureau of Statistics (2016). Report on Household Income and Expenditure Survey (HIES) 2016.

[6] Chikkamath, M., Atteri, B.R., Srivastava, S.K. and Roy, S. 2012. Factors influencing consumer's behaviour for vegetable purchase. Vegetable Science. 39 (1): 35-39.

[7] Finzer, L., Ajay, V., Ali, M., Shivashankar, R., Goenka, S., \& Sharma, P. et al. (2013). Fruit and Vegetable Purchasing Patterns and Preferences in South Delhi. Ecology Of Food And Nutrition, 52(1), 1-20. http://dx.doi.org/10.1080/03670244.2012.705757

[8] Herath US. Consumer Behavior and Attitudes in Purchasing Vegetables. Agri Res\& Tech: Open Access J. 2019; 20(2): 556123. DOI: 10.19080/ARTOAJ.2019.20.556123

[9] Imtiaz, E. K., Aziz, K. M., \& Bhuiyan, M. A. (2007, October 8). A Research on Super-store Business in Bangladesh-Concentration Area Includes the Factors Facilitates its Expansion. Retrieved June 18, 2020, from slideshare.net: https://www.slideshare.net/shumahbub/final-reporton-super-store

[10] Kanchan Singh and Neeraj. 2018. A Study on Factors Affecting Consumers Decision to Purchase Vegetables. Int. J. Curr. Microbiol. App. Sci. 7(02): 1211-1222. doi: https://doi.org/10.20546/ijcmas.201 8.702 .149

[11] Market Insight: Supermarket Industry in Bangladesh - Part 1. (2016, February 15). Retrieved from LightCastle Partners: https://www.lightcastlebd.com/insights/2015/02/16/market-insight-supermarketindustry-bangladesh

[12] Masoom, M. R., Pasha, S. H. A., \& Asif-Ur-RAHMAN, S. M. (2015). Factors affecting the consumer purchasing decisions of perishable foods: Exploring the attitudes and the preferences. Management Dynamics in the Knowledge Economy, 3(3), 509.

[13] Report of a Market Study on Fresh Vegetables Market in Kenya -Consumer's Survey (2015) Research Solutions Africa (RSA) Ltd, Ministry of Economic Affairs, Agriculture and Innovation, Kenya.

[14] Slamet, A., \&Nakayasu, A. (2016). Consumers' Choice for Vegetable Market Channels in Indonesia. Kne Life Sciences, 3(3), 167. http://dx.doi.org/10.18502/kls.v3i3.386

[15] Sinha PK, Arindam, Banerjee, Dwarika PU (2002) Deciding Where to Buy: Store Choice Behavior of Indian Shoppers. Vikalpa: The Journal for Decision Makers 27(2): 13-28.

[16] Solgaard, H. S., \& Hansen, T. (2003). A Hierarchical Bayes Model of Choice between Supermarket Formats. Journal of Retailing and Consumer Services 10(3), 168-180. 
[17] Thomas, T., \&Gunden, C. (2012). Investigating consumer attitudes toward food produced via three production systems: Conventional, sustainable and organic. Journal of Food, Agriculture \& Environment Vol.10 (2), 55-58

[18] Top 5 Online Vegetable Markets in Bangladesh. (2018, March). Retrieved June 16, 2020, from Deshiz: https://deshiz.com/online-vegetable-markets-bangladesh.

\section{AUTHORS' BIOGRAPHY}

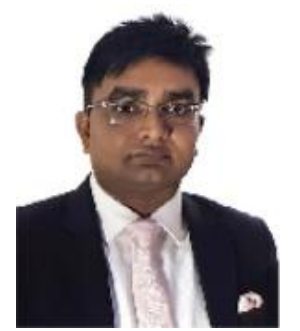

Dr. Rezwanul Huque Khan is currently serving as an Associate Professor at the Institute of Business Administration (IBA), University of Dhaka (DU), Bangladesh. He is involved with different ICT projects initiated by the government aiming Digital Bangladesh. Dr. Rezwan is a Commonwealth Scholar and pursued his $\mathrm{PhD}$ from University of Warwick, UK. He has been in academia for more than fifteen years and actively involved in research. His research interests relate to the transformative potential of digital technology as it pervades modern business and entrepreneurship. Dr. Rezwan's research focuses on digital innovation, entrepreneurship, consumer behavior in different digital platforms (e-banking, e-commerce etc.) and BoP markets. His recent articles have been published in the leading local journals and international outlets such Journal of Business Administration, Journal of Business Studies, Teachers' World, European Journal of Business and Research, and International Journal of Managerial Studies and Research.

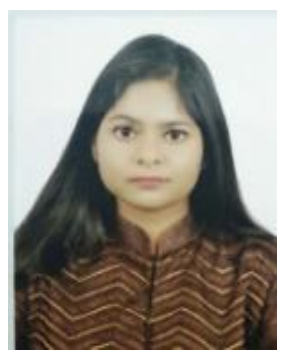

Farah Naz Aditi is a graduate of the Institute of Business Administration, University of Dhaka with a major in Finance. She is currently working as an Assistant Manager in the Central Finance Team of Standard Chartered Bank in Bangladesh. Her research interests are in the fields of Behavioural Finance and Consumer Behaviour. She is a contributor to the Youth Segment of The Financial Express and is passionate about writing on educational and professional trends. Her recent article has been published in the Global Journal of Management and Business Research.

Citation: Dr. Rezwanul Huque Khan, Farah Naz Aditi. "Purchasing Vegetables from Different Channels: A Comparative Study on Factors Affecting the Choice of Channel" International Journal of Managerial Studies and Research (IJMSR), vol 8, no. 7, 2020, pp. 16-24. doi: http:// dx.doi.org/10.20431/2349-0349.0807002.

Copyright: ( $) 2020$ Authors. This is an open-access article distributed under the terms of the Creative Commons Attribution License, which permits unrestricted use, distribution, and reproduction in any medium, provided the original author and source are credited. 